\title{
Reflections on the Development of Electric Business in Counties
}

\author{
Jingping Wang \\ Yiyang Vocational and Technical College, Yiyang, Hunan, 413000, China
}

\begin{abstract}
With the development of information technology, e-commerce has gradually become an important part of economic development, and the county economy as the basic unit of Chinese economic development, how to use the hot electric business as a breakthrough in the county economic development is essential for Chinese county economic transformation and upgrading. This paper analyzes the main problems and suggestions in the development of county electric business from the present situation, and elaborates the county economy development in detail.
\end{abstract}

Keywords electricity business; county economy; problems; suggestion

\section{Introduction}

The development of county economy belongs to the basic unit of economic development of our country, which is often subject to various kinds of pressures. For example, the restriction of geographical area restricts the investment and environment, and the transformation and development of the industry are restricted. With the development of network information, the county economy has become more and more demand for the development of electricity supplier, rural surplus labour force and the diversification of industrial structure. The deepening of e-commerce can effectively promote per capita income and the development of the whole economy. 


\section{The current development of county electricity business status}

In recent years, with the development of Chinese network economy, e-commerce gradually detonated county economy. In 2013, Chinese e-commerce released 100 counties, 76 counties have entered Chinese top 100 counties, among which Zhejiang, Jiangsu and Fujian are the most prominent. The development of these hundred counties has boosted Chinese economic level. According to the county power companies released in 2014 research report shows that the county electric business to drive the local economic development. The "Green Paper on Small and Medium-sized Cities in 2014" was released, and the county-level economic units, as well as the competition level and affluence, were appraised. Shandong, Zhejiang and Jiangsu provinces became the main provinces of the top 100 counties. The development of these provinces is due to the development of electric business led to the overall economic development, which we can see the development of county business is an inevitable trend, with its distinctive features and a variety of development model.

\section{The main problem in the county electricity business development}

\subsection{Standardization and brand issues of agricultural products}

Agriculture is not industrial, agricultural products can not be the same as industrial products, standardized output through the production of uniform products. At present, Chinese agricultural production mainly to scattered small farmers, which more affected the standardization of agricultural products, the same product may be the same batch of output of agricultural products are also different, consumers are difficult to accept the description and the physical gap between the products, Low degree of standardization of agricultural products, product safety and trust has become a big problem.

With the development of electric business gradually mature, increasingly fierce market competition, agricultural products into the electricity market, is bound to undergo a severe test. At present, there are two main types of agricultural products in the county, one is the agricultural products dry goods category, the other is the fresh agricultural products, the former into the market and the traditional dry goods market competition, because the lack of brand can only enter the low-cost marketing errors.

\subsection{County logistics and electronic business services}

According to the current survey of logistics for the county area, such as SF, Yuantong, STO, rhyme and postal courier companies, the annual amount of receipts and dispatching less, in addition to many postal areas, other express basically Unable to deliver. 
On the one hand, because the county, especially in rural areas, scattered, high cost of distribution, long time and low efficiency; the other hand, the county people lack the concept of electricity consumption, consumption scale, logistics companies lack of scale support, County logistics system development is slow.

Lack of electricity business services county enterprises is restricting the development of electric business is another problem. Chinese county-level power supplier base is weak, the county electric power companies are small, can not support electric business service enterprises, and electric business service enterprises is to support the development of county business, the formation of electricity business ecological environment key.

\subsection{Understanding the electricity business talent problem}

Many rural people did not come into contact with such concepts, some grassroots cadres are also very strange, and even some of the leading cadres of the county is also a smattering of the knowledge of the concept of micro-marketing, micro-marketing concept. Misunderstanding there are two main, the electricity business as a marketing channel or the electricity business completely out of line with the industry, ignoring the combination of online and offline, electricity providers and industry integration. On the other hand, the lack of electricity business is also a bottleneck in the development of county business.

\subsection{Planning and government thrust issues}

Business development launched a vigorous "industrial down" campaign. Industrial products down, the consumption level of farmers have been improved, the electric business has a preliminary understanding, but to stimulate the county economy, the development of "agricultural uplink" there is no favourable measures. Therefore, the development of county-level electricity providers need to carry out scientific planning, "industrial down" to improve the electricity business development environment, more importantly, "agricultural uplink" development of county economy.

\section{The development strategy of the county electricity business}

With the spread of electricity providers in the county area, how to make the development of electric business more security and stability is the development of important issues to be considered.

\subsection{The transformation of county economic development based on the development of electricity business}

With Chinese agricultural products into the market, the domestic price upside down, agricultural efficiency, farmers continue to increase the difficulty of increasing gradually, so for the county region's economic development is facing a 
huge challenge. Chinese urbanization in recent years in-depth, accelerate the task of county economic construction gradually increased. The development of county electric business can be related to entrepreneurship, employment and help farmers to increase income, so the development of county economy can be based on the development of electricity providers to achieve. But the relatively slow spread of the county area network, infrastructure is limited and the government should focus on long-term, moderate support. At the same time in public services, should also be real-time encouragement. For the county area of the development of electricity providers, the government should implement the investment, training excellent electrical business. Such as the county region to develop electricity providers, the county's warehousing logistics, operational services and personnel training and so have a great role in promoting.

\subsection{The creation of electric business park}

The development of electronic business has already belonged to a highly refined division of labour industry, so the chain of business for the electronic business, including product production, photography, art design and business training, marketing, and warehousing and logistics operations. Therefore, the establishment of electronic business park can be effectively involved in these enterprises together, on the one hand to reduce costs and improve transaction efficiency, but also to promote the development of electronic business chain.

From the government point of view, the establishment of electric business park can be more effective for the popularity of electricity policy. For the main business, the Pioneer Park to provide them with a more appropriate business and development platform. Therefore, the establishment of Pioneer Park can effectively enhance the county area of the development of electricity providers.

\subsection{The training and the introduction of electricity business talent}

According to official data, at present there are nearly 800 million farmers in China, 200 million migrant workers, the lack of talent in the county, not to mention electricity business talent. According to research and analysis shows that the next few years, the gap in electricity business talent in the 50 million or so, and the current college for the training of electric business personnel employment rate of only $20 \%$, low employment reasons for the lack of time students, The second is the enterprise urgently lack of electricity business talent, but the lack of talent training capacity, leading to lower rates of employment of college students and business talent lack of contradiction. Therefore, the introduction of county business personnel can not rely solely on graduate students, on the one hand to do a good job in county business training, on the county's various types of people to do business awareness, electricity business skills training, and gradually cultivate electricity business talent. On the other hand, the government needs to attract young migrant workers or entrepreneurs to return home, to enrich the county to the ranks of business personnel. 


\section{The proposals to promote the development of electric business}

\subsection{Improve government support and make key breakthroughs}

The government, in the light of the situation in each county, has formulated a reasonable policy of supporting electricity suppliers, and has increased its investment in technology and capital. At the same time the government to give full play to the leading role, leading enterprises to increase capital investment, so that enterprises become the main supplier of electricity development. In addition the local government to simplify e-commerce business approval procedures and shorten the approval time, the market access, land, water and other resources to relax. The government can also serve as a guide to set up the county area of the electronic business associations, to build communication platform, opening up sources of supply within and outside the county channels.

\subsection{Develop rural electricity providers and promote the development of county business by the strategy of rural areas around the city}

The rapid development of electricity providers need to have a flow of products, the second is to have sufficient technical personnel. The government takes the lead in formulating standards for agricultural products, creating brand-name agricultural products, innovating new models for agricultural electricity providers, promoting infrastructure construction in rural areas, strengthening the rural logistics system, cultivating rural electricity providers, developing rural electricity suppliers, the strategy to promote the development of county business.

\subsection{Establish an effective electricity business propaganda and increase the electricity business thinking consciousness}

Each county area government can increase the electricity business propaganda, the national "power to 100 good county" as well as the electric business is more developed county, local electric business service consciousness are strong, so the government can from all aspects for entrepreneurs and electricity Business enterprises fully aware of the role of electricity providers. At the same time to encourage people to boldly try and explore, with the help of the development of the Internet to strengthen the development of business thinking innovation. In addition you can use the success of the role model, driving more business development.

\subsection{Develop the special industry}

The development path and the level of production are different, so the development of electricity providers need to local conditions, highlighting the innovation and development characteristics, the use of local characteristics for the development point, the rational distribution of the region, Improve product quality within the county area, optimize the product structure, promote the establishment of leading enterprises in the region, and then lead the development 
of electric business. While the development strategy to establish standardization, industrialization and large-scale requirements, do a good job of business credit, so as to improve the county business development.

\section{Conclusion}

The electricity business is indeed a driving effect of the local economy for the county region of electricity providers, but at the same time various reasons restricting the development of county business. As we all know the logistics, logistics and distribution in rural areas is relatively backward, the distance between many villages is long, it is undoubtedly a problem to be solved for logistics and distribution staff. In addition, the more popular electricity providers in Zhejiang, Jiangsu and other places have a more mature experience in electricity business and electricity business enterprises, and some more remote areas due to transportation and other transportation costs, many mature electric business enterprises do not want to get involved, but also restricts the comprehensive development of county business. So in order to do a good job in county business development, the local government needs to clear the way, boldly to encourage the development of electricity business, the introduction of foreign capital, training professionals, establish a sound business system, the use of local characteristics, build county brand to form a county business ecosystem, driving the county economy as a whole.

\section{References}

[1] Du Min, Han Caixia, Tong Jianqiang. Study on E-commerce Driving County Economic Development. Modern Business, 55(12), pp.68-70, 2011

[2] Shi Jianbin. Research on the Development of Guangxi County-level Finance to Help County-level Electric Business Development. Budget Journal of Regional Finance 8 (5), pp.87- 91, 2013

[3] Li Bo. Study on the Problems and Countermeasures of County E-commerce Development - Taking Gaoqing County as an Example. Information Technology and Informatization, 12(10), pp. 18- 20, 2012

[4] Zhong Cheng. Strategic Thinking on the Development of County Electric Traders in Changting County, Fujian Province. Journal of Fuzhou University, 9(6), pp.58- 61, 2011

[5] Cai Yun, Yin Ronglin. Internet + Agriculture: The Dilemma and Breakthrough in the Development of Rural Electric Business - Based on the Investigation of Changxing County in Zhejiang Province, Economist. 8(4), pp.8587,2014 